\title{
Aroma and Sensory Profiles of Sauvignon Blanc Wines from Commercially Produced Free Run and Pressed Juices
}

\author{
Katie Parish-Virtue ${ }^{1} \mathbb{D}$, Mandy Herbst-Johnstone ${ }^{1,+}{ }^{,}$, Flo Bouda ${ }^{2}$, Bruno Fedrizzi ${ }^{1}$, Rebecca C. Deed ${ }^{1,3}$ (D) \\ and Paul A. Kilmartin 1,*D
}

1 Wine Science Programme, School of Chemical Sciences, The University of Auckland, Private Bag 92019, Auckland 1142, New Zealand; kpar121@aucklanduni.ac.nz (K.P.-V.); mandy.herbst-johnstone@gribbles.co.nz (M.H.-J.); b.fedrizzi@auckland.ac.nz (B.F.); rebecca.deed@auckland.ac.nz (R.C.D.)

2 Delegat Limited, 172 Hepburn Rd, Henderson, Auckland 0602, New Zealand; flo.bouda@delegat.com

3 School of Biological Sciences, The University of Auckland, Private Bag 92019, Auckland 1142, New Zealand

* Correspondence: p.kilmartin@auckland.ac.nz

† Current address: Gribbles Scientific, Dunedin, New Zealand.

Citation: Parish-Virtue, K.; Herbst-Johnstone, M.; Bouda, F.; Fedrizzi, B.; Deed, R.C.; Kilmartin, P.A. Aroma and Sensory Profiles of Sauvignon Blanc Wines from Commercially Produced Free Run and Pressed Juices. Beverages 2021, 7, 29. https://doi.org/10.3390/ beverages7020029

Academic Editors:

Stamatina Kallithraka and

Matteo Marangon

Received: 29 April 2021

Accepted: 20 May 2021

Published: 25 May 2021

Publisher's Note: MDPI stays neutral with regard to jurisdictional claims in published maps and institutional affiliations.

Copyright: (c) 2021 by the authors. Licensee MDPI, Basel, Switzerland. This article is an open access article distributed under the terms and conditions of the Creative Commons Attribution (CC BY) license (https:/ / creativecommons.org/licenses/by/ $4.0 /)$.

\begin{abstract}
Sauvignon blanc is the most important grape cultivar within the New Zealand wine industry, and wines from the Marlborough region are renowned for their intense aromas including tropical, passionfruit, and green capsicum. Quality Sauvignon blanc wines are usually made from free run juice, although press fractions can be included. The chemical aroma composition and sensory profiles of two wine sets made from three press fractions (free run, light press and heavy press) were compared. The compounds 3-mercaptohexan-1-ol and 3-mercaptohexyl acetate were found to decrease between free run and heavily pressed wines while hexyl acetate, hexanol, and benzyl alcohol increased. The accompanying sensory analysis showed that free run wines were marked by aromas of Passionfruit/sweaty, Boxwood and Fresh green capsicum, while the heavy pressed wines were described by French vanilla/bourbon, Floral and Banana lolly attributes, consistent with the aroma chemical composition.
\end{abstract}

Keywords: Marlborough Sauvignon blanc; press fractions; free run; aroma compounds; descriptive analysis; GC-MS

\section{Introduction}

Vitis vinifera cv. L. Sauvignon blanc is a well-established cultivar in Marlborough, New Zealand, with wines being characterised by passionfruit and tropical aromas, as well as herbaceous, capsicum and grassy tones. The polyfunctional mercaptans 3-mercaptohexan1-ol (3MH) and 3-mercaptohexyl acetate (3MHA), also described as varietal thiols, are prominent in Sauvignon blanc wines and produce nuances of boxwood, grapefruit, passionfruit, and guava [1,2]. In previous surveys of commercial Marlborough Sauvignon blanc wines, average levels of 3MH were between 3786 and $7080 \mathrm{ng} / \mathrm{L}$, for two different years, while average levels of 3MHA ranged from 395 to $516 \mathrm{ng} / \mathrm{L}$ [3].

Higher concentrations of $3 \mathrm{MH}$ and $3 \mathrm{MHA}$ have been found in wines made from free run juices, as opposed to light and heavy pressed counterparts [2,4,5], despite higher concentrations of cysteine and glutathione conjugates of $3 \mathrm{MH}$ being found in the pressed juices $[2,6]$. The extent of juice oxidation, indicated by the degree of browning at $420 \mathrm{~nm}$ absorbance, was identified as a key factor limiting the ability of juices to produce more elevated concentrations of wine 3MH and 3MHA [2]. To counteract the effects of juice oxidation, subsequent trials have shown that antioxidant additions at harvest of sulfites alone, or supplemented with ascorbic acid or glutathione, are effective in maximising the formation of 3MH and 3MHA in Sauvignon blanc wines [7-9]. Indeed, with sulfite additions made to must, $3 \mathrm{MH}$ and $3 \mathrm{MHA}$ concentrations were not diminished, and even 
increased, with must oxygenation, which leads to decreases in the polyfunctional mercaptans in musts that are low in sulfites [9]. The ability of antioxidant additions at crushing to produce wines with elevated $3 \mathrm{MH}$ and $3 \mathrm{MHA}$ concentrations has been recently extended to Pinot gris and Chardonnay wines [10].

Further volatile compounds are important to the aroma of Sauvignon blanc wines. The methoxypyrazines and certain $\mathrm{C}_{6}$ alcohols cis-hexen-1-ol and trans-hexen-1-ol can impart capsicum, grassy, and leafy aromas $[3,11,12]$ to the wines. The presence of some $\mathrm{C}_{6}$ alcohols, formed during grape processing through the action of lipoxygenases [7], has been shown to increase during Emir grape pressing, with hexanol being 3.2 times more abundant in the pressed juice than the free run fraction [13]. Terpenes are compounds that are less immediately associated with Sauvignon blanc wine aroma, although their presence in this variety has been recognised to impart floral notes [3,14,15]. Several winemaking factors can alter the levels of terpenes in a finished wine, including juice temperature, blending, and skin contact time [16], the latter of which increases with the time that grape must spends in the press. Other compounds that can contribute to wine aroma include fermentative esters, fatty acids, and higher alcohols $[17,18]$. Several esters and other aroma compounds have already been reported in Marlborough Sauvignon blanc at levels higher than their perception thresholds, such as ethyl octanoate and isoamyl acetate [3].

The present paper describes the chemical and sensory profiles of Sauvignon blanc wines produced from three commercially recognisable juice fractions. The information is directed towards both researchers and winemakers, as it helps to build a basic understanding of how wine aroma is modulated based on juice extraction. This is an especially important topic for winemakers aiming to achieve the maximum juice extraction from their Sauvignon blanc harvests.

\section{Materials and Methods}

\subsection{Chemicals}

Internal standards $\mathrm{d}_{2}-3 \mathrm{MH}$ and $\mathrm{d}_{2}-3 \mathrm{MHA}$ were synthesised at The University of Auckland [19]. All other standards used for the aroma analyses, as well as those included in the sensory panel, were of purity $\geq 97 \%$. Unlabeled 3-mercaptohexyl acetate was from Oxford Chemicals (Hartlepool, United Kingdom), while 3-mercaptohexan-1-ol, and those used for the analysis of other volatiles, 3,4-dimethlyphenol and DL-3-octanol, were from Acros Organics (Morris Plains, NJ, USA). Aldrich supplied 3-isobutyl-2-methoxypyrazine (Sheboygan Falls, WI, USA) as well as 4-decanol, which was the third non-deuterated standard used for the quantification of other volatiles. Deuterated internal standards

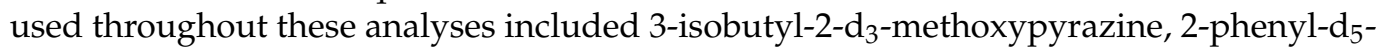
alcohol, hexanal- $\mathrm{d}_{12}, \mathrm{n}$-hexyl- $\mathrm{d}_{11}$ alcohol, ethyl butyrate- $\mathrm{d}_{3}$, ethyl hexanoate- $\mathrm{d}_{11}$, ethyl octanoate- $\mathrm{d}_{15}, 3$-methylbutyl acetate- $\mathrm{d}_{3}$, $\mathrm{n}$-hexyl acetate- $\mathrm{d}_{3}$, 2-phenylethyl acetate- $\mathrm{d}_{3}, 3$ methyl-1-butyl- $\mathrm{d}_{2}$-alcohol and $\left( \pm\right.$ )-linalool- $\mathrm{d}_{3}$ as supplied by CDN Isotopes (Quebec, $Q C$, Canada). Additional chemicals used in sensory analysis reference standards: 4-mercapto-4methylpentan-2-one (4MMP), hexanol and cis-3-hexen-1-ol from Aldrich (Sheboygan Falls, WI, USA), isoamyl acetate from Univar (Sydney, Australia), hexyl acetate and phenylethyl acetate from Across Organics (Morris Plains, NJ, USA). Copper sulfate was from Riedel-de Haën (Seelze, Germany).

Ultrapure water was from a Barnstead Nanopure Diamond (ThermoFisher Scientific, Waltham, MA, USA) with resistivity at $18.2 \mathrm{M} \Omega \mathrm{cm}$. Solid $\mathrm{CO}_{2}$ (food grade), carbon dioxide (food grade), nitrogen (industrial grade), argon (industrial grade) and helium (instrument grade) were supplied by BOC Gases NZ Ltd. (Blenheim/Auckland, New Zealand). Potassium metabisulfite was from Enartis $\mathrm{E}^{\circledR}$ (Trecate, Italy).

\subsection{Grape Processing and Winemaking}

Machine harvested Sauvignon blanc grapes from vineyards located in the Wairau valley (set A) and Awatere valley (set B) of Marlborough, New Zealand, were used during this trial. Following normal commercial practices, both sets of grapes received potassium 
metabisulfite (PMS) additions at a rate of approximately $60 \mathrm{~g} / \mathrm{t}$ during the harvesting process, by direct addition to the gondola. The grapes were deposited in a winery hopper, destemmed/crushed (Vaslin Bucher Delta E8, Chalonnes-sur-Loire, France), and then pumped into a clean Bucher 350 Xpert pneumatic press (Chalonnes-sur-Loire, France). The press from which the set A samples were collected contained $53.6 \mathrm{t}$ of grape must, while the set B press contained $43.0 \mathrm{t}$, with both subjected to the same cycle and having a maximum pressure of 1.8 bar.

Juice samples were collected in $25 \mathrm{~L}$ plastic containers at three different points during the pressing cycle. These were defined as Free Run (FR), Light Press (LP), and Heavy Press (HP), and were collected when the pressing cycle had yielded $250 \mathrm{~L} / \mathrm{t}$ (approx. 0.0-0.4 bar), $660 \mathrm{~L} / \mathrm{t}$ (approx. 0.6-1.6 bar) and $780 \mathrm{~L} / \mathrm{t}$ (approx. 1.4-1.8 bar) of juice, respectively. An extra $500 \mathrm{~mL}$ sample was taken to conduct a post pressing analysis (Table 1) at the onsite laboratory for soluble solids ( ${ }^{\circ}$ Brix), $\mathrm{pH}$ and total acidity (Maselli Misure SA03), with free $\mathrm{SO}_{2}$ and total $\mathrm{SO}_{2}$ by aspiration, percentage solids by weight and yeast assimilable nitrogen (YAN) by Megazyme assay kits (K-LARGE and PANOPA, Wicklow, Ireland). To help protect the juice from further oxidation, the levels of free $\mathrm{SO}_{2}$ were topped up to $25 \mathrm{mg} / \mathrm{L}$ through additions of concentrated PMS solutions after collection. Juice samples were cold settled for $16 \mathrm{~h}$ at $3{ }^{\circ} \mathrm{C}$ before racking into clean $25 \mathrm{~L}$ plastic containers protected by a small pellet of solid $\mathrm{CO}_{2}$. All juice samples were then transferred to The University of Auckland (North Island, New Zealand) by a refrigerated truck at $4{ }^{\circ} \mathrm{C}$. At Auckland, they were analysed for polyphenols by HPLC (Agilent 1100 coupled to a G1315B Diode-array UV-Vis detector and an ESA CoulochemIII electrochemical detector) as previously described by Maggu et al., 2007 [20], before undergoing fermentation.

Table 1. Post-pressing analysis of experimental juices.

\begin{tabular}{ccccccc}
\hline & \multicolumn{3}{c}{ Wairau Valley (A) } & \multicolumn{3}{c}{ Awatere Valley (B) } \\
\hline & FR & LP & HP & FR & LP & HP \\
\hline Juice Temperature $\left({ }^{\circ} \mathrm{C}\right)$ & 7.4 & 10.3 & 11.4 & 20.9 & 20.3 & 20.6 \\
Soluble Solids $\left({ }^{\circ}\right.$ Brix) & 21.5 & 22.0 & 21.6 & 23.0 & 23.0 & 23.1 \\
$\mathrm{pH}$ & 3.19 & 3.79 & 4.05 & 3.37 & 3.69 & 3.89 \\
Total Acidity $(\mathrm{g}$ tartaric acid/L) & 10.4 & 7.5 & 8.2 & 12.1 & 9.5 & 9.4 \\
Free $\mathrm{SO}_{2}(\mathrm{mg} / \mathrm{L})$ & 21 & 1 & 0 & 14 & 1 & 0 \\
Total $\mathrm{SO}_{2}(\mathrm{mg} / \mathrm{L})$ & 42 & 8 & 7 & 41 & 8 & 10 \\
Solids $(\%)$ & 5.0 & 0.7 & 0.2 & 5.0 & 3.5 & 0.8 \\
\hline
\end{tabular}

$\overline{\mathrm{FR}}=$ Free Run, LP $=$ Light Press and HP = Heavy Press.

Upon arrival in Auckland, the juices were stirred, and triplicate $5 \mathrm{~L}$ demi-johns were taken from each juice treatment under a blanket of $\mathrm{CO}_{2}$ gas. The juices were then placed in a $15{ }^{\circ} \mathrm{C}$ cool room and once juice temperatures had reached $12.5^{\circ} \mathrm{C}$, they were inoculated with Lalvin EC1118 yeast (Saccharomyces cerevisiae, Lallemand Brewing) at a rate of $12.5 \mathrm{~g} / \mathrm{hL}$, which had been prepared using the rehydration agent Dynastart (Laffort) at an equal rate. Each demi-john was then gently swirled, fitted with an airlock and weighed, and the fermentation was monitored by tracking the weights daily.

Forty-eight hours after inoculation, a $50 \mathrm{mg} / \mathrm{L}$ addition of Nutristart (Laffort) was made to each treatment, to supplement YAN, which had been recorded by the winery at $222 \mathrm{mg} / \mathrm{L}$ and $220 \mathrm{mg} / \mathrm{L}$ for juice sets A and B, respectively. At the end of fermentation, determined by a constant weight for 5 to 7 days, the wines were racked from their lees into another $5 \mathrm{~L}$ glass demi-john, which had previously been gassed with $\mathrm{CO}_{2}$. An addition of free $\mathrm{SO}_{2}$ at a rate of $25 \mathrm{mg} / \mathrm{L}$ was made to aid yeast inactivation and prevent further fermentation. The headspace above the wines was decreased by the addition of glass marbles before cold settling at $-4{ }^{\circ} \mathrm{C}$ for 18 days, which was assisted by a $50 \mathrm{~mL}$ addition of a freshly prepared $5 \% w / w$ solution of sodium-calcium bentonite.

After settling, $30 \mathrm{~mL}$ samples were collected to determine free and total $\mathrm{SO}_{2}$ levels using a FIAstar ${ }^{\mathrm{TM}} 5000$ Analyzer in a 2-channel configuration fitted with a 5027 FOSS Sampler (FOSS, Hillerod, Denmark). These results were used to adjust each wine's free 
$\mathrm{SO}_{2}$ level to $25 \mathrm{mg} / \mathrm{L}$ at the time of bottling. Another $30 \mathrm{~mL}$ of wine was taken for the analysis of basic wine parameters, including ethanol content (\% volume), residual sugar, TA, volatile acidity (both expressed in $\mathrm{g} / \mathrm{L}$ ) and $\mathrm{pH}$, using a FOSS WineScan ${ }^{\mathrm{TM}}$ FT120 Basic equipped with a 5027 FOSS Sampler (FOSS, Hillerod, Denmark). Each fermentation produced four $750 \mathrm{~mL}$ bottles, which were screw capped and placed in a $5^{\circ} \mathrm{C}$ cool room until chemical and sensory analysis was conducted approximately 2 months later.

\subsection{Analysis of Polyfucntional Mercaptans}

The polyfunctional mercaptans 3-mercaptohexan-1-ol (3MH) and 3-mercaptohexyl acetate (3MHA) were analysed using a previously revised method [2,7]. Changes to the original method include the omission of 4-methoxy-2-methyl-2-mercaptobutane as an internal standard and the preparation of the calibration curves using spiked model wine (ultrapure water containing 12\% $v / v$ ethanol, $5 \mathrm{~g} / \mathrm{L}$ tartaric acid and adjusted to a $\mathrm{pH}$ of 3.2), with increasing amounts of the analysed polyfunctional mercaptans, to gain ten calibration points for each compound $\left(\mathrm{R}^{2}=0.998\right.$ and 0.999 for 3MH and 3MHA, respectively, Supplementary Table S1). Selective ion monitoring (SIM) positive mode was used to detect $3 \mathrm{MH}$ and $3 \mathrm{MHA}$ and their internal standards $\left(\mathrm{d}_{2}-3 \mathrm{MH}\right.$ and $\left.\mathrm{d}_{2}-3 \mathrm{MHA}\right)$.

\subsection{Methoxypyrazine Analysis}

Analysis of isobutyl methoxypyrazine (IBMP) concentrations was conducted according to a HS-SPME/GC-MS method first developed by Parr et al. [21] and since revised as described in Parish et al. [22]. Briefly, $1.6 \mathrm{~mL}$ of wine is added into a $20 \mathrm{~mL}$ amber headspace vial along with $6.4 \mathrm{~mL}$ of ultrapure water, $3 \mathrm{~g}$ of sodium chloride, $2 \mathrm{~mL}$ of $4 \mathrm{~mol} / \mathrm{L}$ sodium hydroxide and internal standard (3-isobutyl-2- $\mathrm{d}_{3}$-methoxypyrazine at $20.9 \mathrm{ng} / \mathrm{L}$ ). Prepared samples were agitated rather than stirred for five minutes at $40{ }^{\circ} \mathrm{C}$ and $500 \mathrm{rpm}$ with desorption occurring in splitless mode at $250^{\circ} \mathrm{C}$ for $10 \mathrm{~min}$ with helium used as the carrier gas at a flow rate of $1.806 \mathrm{~mL} / \mathrm{min}$. Mass spectra were recorded in electron impact SIM positive mode and the calibration curve $\left(R^{2}=0.999\right.$, Supplementary Table S1) was obtained by analysing ten increasing concentration points of a commercial Pinot Noir wine (Leaning Rock, Central Otago, New Zealand), which had been spiked with IBMP.

\subsection{Analysis of Other Volatiles}

Analysis of other volatiles included aroma compounds from the ester, terpene, norisoprenoid, cinnamate, fatty acid and higher alcohol families using a HS-SPME/GC-MS method [23]. Additional volatiles assessed included cis/trans-rose-oxide, 4-vinylphenol, and 4-vinylguiacol. SIM mode was used to detect the volatile compounds and calibrations were carried out by spiking a model white wine (ultrapure water containing $12 \% \mathrm{v} / \mathrm{v}$ ethanol, $5 \mathrm{~g} / \mathrm{L}$ tartaric acid and adjusted to a $\mathrm{pH}$ of 3.2) with increasing amounts of the analysed compounds. Additional information regarding this analysis can be found in Supplementary Table S1.

\subsection{Sensory Analysis}

Ethics approval no. 8306, was granted by The University of Auckland Human Participants Ethics Committee (UAHPEC). The panel consisted of 15 postgraduate students, eight males and seven females aged between 21 and 38, enrolled in the Wine Science Programme at The University of Auckland. The wines were evaluated only with the nose, and the panel received two weeks of training, three sessions per week, in descriptive sensory analysis. Twelve reference standards were provided based upon previous studies [3,24], and the panelists decided upon the attribute names by consensus (Supplementary Table S2). Training involved familiarization with the reference standards using triangle tests and an unstructured $150 \mathrm{~mm}$ line scale anchored as "lowest" and "highest". Commercial Sauvignon blanc wines from both France and New Zealand (Glengarry, Auckland) were used to examine the consistency of the individual panelists. This was undertaken by asking the 
panel to evaluate these wines using the line scale and then applying principal component analysis (PCA) and eggshell plots to review the consistency of the panel.

During evaluation, sets of reference standards were available to the panelists. A quantity of $30 \mathrm{~mL}$ of wine was aliquoted into a $215 \mathrm{~mL}$ wine glass, covered with a petri dish and disguised using black wine coats and randomised three-digit codes. Wines were evaluated in a random order inside a well-ventilated and lit room that was split into fifteen evaluation stations, each displaying two wines. Once all members of the panel had evaluated the wines at their station, they moved to a different pair of wines for the next wine evaluations. Compulsory breaks of $10 \mathrm{~min}$ between every 10 wines were used to help combat sensory fatigue. All fermentation triplicates of the wines were assessed in duplicate over three consecutive days.

\subsection{Data Analysis}

Chemical data was evaluated by Agilent MassHunter A.02.00, with analysis of variance (ANOVA) and Tukey's HSD post-hoc testing for both the chemical and sensory data of each wine set conducted in IBM SPSS 20 (Armonk, NY, USA). Permutational Multivariant ANOVA (PERMANOVA) was then used to explore the overall impact of vineyard and juice fraction on the scaled aroma chemistry data in $\mathrm{R}$ [25] with the package vegan [26]. A Principal Component Analysis (PCA) [27] was conducted using all of the analysed aroma compounds to highlight similarities between the experimental wines and their aroma chemistry composition, with Mardia's criterion [28] used to pull out the specific contributors that are most responsible for the positing of the experimental wines along each principal component. Preliminary sensory data analysis such as missing values was carried out using the open source software PanelCheck version 1.4.0 (http:/ / www.panelcheck.com), accessed on 1 August 2015). For the sensory analysis, multi-way ANOVA was conducted for each wine set, A and B, individually, using "panelist", "sample" and "replicate" (the sample was evaluated twice by each panelist) as the fixed main effects. Spider plots of the sensory data were created using Microsoft Excel. A $p$-value of less than 0.05 has been used to identify significant differences between the pressing treatments within each wine set, be they for aroma compound concentrations or sensory attributes.

\section{Results and Discussion}

\subsection{Post Pressing Juice Analysis}

The post pressing analyses of the experimental juices can be found in Table 1. Juice temperatures ranged from 7.4 to $11.4^{\circ} \mathrm{C}$ for juice set $\mathrm{A}$ and 20.3 to $20.9^{\circ} \mathrm{C}$ for juice set $\mathrm{B}$. These differences are due to the time of day at which the juice was collected and processed, with set $\mathrm{A}$ harvested at approx. $7 \mathrm{am}$ and set B at approx. $11 \mathrm{am}$. Soluble solids ( $\left.{ }^{\circ} \mathrm{Brix}\right)$ showed no particular trend between press fractions within each juice set (A and B), which implies that this parameter was not greatly influenced by pressure and is consistent with a previous study [4]. However, set B juices were slightly higher ( 23.0 to $23.1^{\circ}$ Brix) than set A ( 21.5 to $\left.22.0^{\circ} \mathrm{Brix}\right)$ in soluble solids, which could be due to the factors such as harvest date, site conditions and location, as well as crop yield. As the pressure increased, the $\mathrm{pH}$ also increased, by up to 0.5 units, whilst the TA of the juices decreased, as expected [4,29]. The total solids, expressed as a percentage of weight per volume, also decreased across the press fractions, from around 5\% solids in the FR, to less than 1\% in the HP fractions, which may affect yeast nutrient status and the ability of the juice to remove oxygen in place of phenolic oxidation processes.

The concentration of free and total $\mathrm{SO}_{2}$ also decreased as the pressing cycle progressed (Table 1), to the point that no free $\mathrm{SO}_{2}$ was detected in the HP juices, as commonly occurs in commercial winemaking. This loss of $\mathrm{SO}_{2}$ could be due to prolonged oxygen exposure and the effects of certain more oxidisable polyphenols in the more heavily pressed juices. The effects of juice oxidation were seen in the much lower concentrations of the hydoxycinnamic acid caftaric acid and the Grape Reaction Product, and some loss of catechin, in the LP and HP juices for both juice sets (Supplementary Table S3), trends observed previously [4]. 
At the same time, the concentration of quercetin-3-glucoside in the juices increased as the pressing progressed from FR to HP fractions for both wine sets. The presence of oxidised quinones arising from the oxidation of catechol-containing phenolics has been implicated in the removal of $3 \mathrm{MH}$ from wines, or to limit its formation during fermentation [10]. The higher $\mathrm{pH}$ of the pressed juices may also promote juice oxidation processes and needs to be considered in relation to aroma formation during fermentation [6].

\subsection{Basic Wine Parameters}

The $\mathrm{pH}$ of the finished wines showed an increasing trend from FR to HP for both sets (Supplementary Table S4), consistent with the juice analyses, with some particularly high values seen with the HP wines (ca. 4.5). For each wine set, the FR wines had the greatest total acidity levels, which is consistent with the juice analysis. The amount of volatile acidity showed no consistent trends between the press fractions and covered a narrow range of 0.4 to $0.5 \mathrm{~g} / \mathrm{L}$ for each set. The ethanol content of the wines was typical for a dry white wine, with values ranging from 12.4 to $13.9 \%$, and largely followed the soluble solid $\left({ }^{\circ} \mathrm{Brix}\right)$ levels seen in the juices. The free and total $\mathrm{SO}_{2}$ results from the wine do not show the same decreasing trend between press fractions, as these $\mathrm{SO}_{2}$ levels were measured after the addition of $25 \mathrm{mg} / \mathrm{L} \mathrm{SO}_{2}$ had been made at the end of fermentation.

\subsection{Wine Aroma Analysis}

The results of wine aroma analyses are provided in Table 2. Vineyard (A or B) and Fraction (FR, LP, HP), as well as their interaction, were indicated by PERMANOVA to have a significant influence on the aroma chemistry of the experimental wines. Replicate, as well as its interaction with Fraction, were also considered during the analysis; however, as these were non-significant, they were subsequently removed, with a simplified version of the PERMANOVA results presented in Supplementary Table S5. From this analysis, the fraction of juice used to create an experimental wine was the most influential factor tested, accounting for over $68 \%$ of the variation seen in the aroma chemistry data. As expected, the vineyard from which the grapes originated was also an important contributor to the aroma profiles $(16 \%)$ of the resulting wines, as was the interaction between these two variables $(13 \%)$.

To better understand the relationship between the Fraction and Vineyard factors, the aroma chemistry data were submitted to Principle Component Analysis. Furthermore, to highlight individual compounds that were driving the separation of the experimental wines along PC1 and PC2, Mardia's criterion was consulted. The ensuing biplot, with PC1 explaining $59.1 \%$ of the variation, and PC2 explaining a further $16.7 \%$, can be found in Figure 1. One feature of PCA is the very close positioning of the triplicate fermentations with each other, for each fraction and vineyard. This provides further justification for the removal of this factor from the aforementioned PERMANOVA. 
Table 2. Average concentrations \pm standard deviations of the aroma compounds analysed in the experimental wines.

\begin{tabular}{|c|c|c|c|c|c|c|c|}
\hline \multirow[b]{2}{*}{ Compound } & \multirow[b]{2}{*}{$\begin{array}{c}\text { Concentration } \\
\text { Units }\end{array}$} & \multicolumn{3}{|c|}{ Wairau Valley (A) } & \multicolumn{3}{|c|}{ Awatere Valley (B) } \\
\hline & & FR & LP & HP & FR & LP & HP \\
\hline IBMP & (ng/L) & $4.9 \pm 0.1^{\mathrm{a}}$ & $4.7 \pm 0.2^{\mathrm{a}}$ & $5.1 \pm 0.3^{a}$ & $6.2 \pm 0.2^{\mathrm{a}}$ & $3.7 \pm 0.2^{b}$ & $4.0 \pm 0.3^{b}$ \\
\hline $3 \mathrm{MH}$ & (ng/L) & $971 \pm 55^{\mathrm{a}}$ & $128 \pm 0.4^{b}$ & $123 \pm 11^{b}$ & $2368 \pm 115^{a}$ & $246 \pm 12^{b}$ & $162 \pm 5.3^{b}$ \\
\hline 3MHA & (ng/L) & $290 \pm 47^{\mathrm{a}}$ & $149 \pm 41^{\mathrm{b}}$ & $188 \pm 46^{\mathrm{a}, \mathrm{b}}$ & $705 \pm 87^{\mathrm{a}}$ & $136 \pm 26^{b}$ & $93 \pm 8^{b}$ \\
\hline cis/trans-Rose oxide & $(\mu \mathrm{g} / \mathrm{L})$ & $0.247 \pm 0.010^{\mathrm{a}}$ & $0.394 \pm 0.009^{b}$ & $0.597 \pm 0.019^{c}$ & $0.296 \pm 0.005^{\mathrm{a}}$ & $0.532 \pm 0.014^{b}$ & $0.809 \pm 0.015^{c}$ \\
\hline Linalool & $(\mu \mathrm{g} / \mathrm{L})$ & $4.1 \pm 0.1^{\mathrm{a}}$ & $4.0 \pm 0.2^{\mathrm{a}}$ & $4.4 \pm 0.2^{\mathrm{a}}$ & $6.9 \pm 0.4^{\mathrm{a}}$ & $7.9 \pm 0.3^{b}$ & $9.5 \pm 0.3^{c}$ \\
\hline$\beta$-Citronellol & $(\mu \mathrm{g} / \mathrm{L})$ & $5.3 \pm 0.4^{\mathrm{a}}$ & $6.7 \pm 0.2^{b}$ & $8.7 \pm 0.3^{c}$ & $5.8 \pm 0.1^{\mathrm{a}}$ & $7.6 \pm 0.2^{b}$ & $10.9 \pm 0.3^{c}$ \\
\hline Nerol & $(\mu \mathrm{g} / \mathrm{L})$ & $3.4 \pm 0.2^{\mathrm{a}}$ & $3.9 \pm 0.2^{\mathrm{a}}$ & $6.4 \pm 0.2^{b}$ & $4.2 \pm 0.2^{\mathrm{a}}$ & $4.1 \pm 0.2^{\mathrm{a}}$ & $6.9 \pm 0.2^{b}$ \\
\hline$\beta$-Damascenone & $(\mu \mathrm{g} / \mathrm{L})$ & $4.4 \pm 0.4^{\mathrm{a}}$ & $2.4 \pm 0.1^{\mathrm{b}}$ & $2.1 \pm 0.1^{\mathrm{b}}$ & $3.0 \pm 0.1^{\mathrm{a}}$ & $1.7 \pm 0.1^{\mathrm{b}}$ & $1.4 \pm 0.1^{\mathrm{c}}$ \\
\hline$\beta$-Ionone & $(\mu \mathrm{g} / \mathrm{L})$ & $0.281 \pm 0.002^{\mathrm{a}}$ & $0.242 \pm 0.002^{b}$ & $0.218 \pm 0.005^{c}$ & $0.301 \pm 0.009^{a}$ & $0.241 \pm 0.010^{b}$ & $0.247 \pm 0.010^{b}$ \\
\hline Hexanol & $(\mu \mathrm{g} / \mathrm{L})$ & $1199 \pm 74^{\mathrm{a}}$ & $3346 \pm 154^{\mathrm{b}}$ & $10,195 \pm 420^{\mathrm{c}}$ & $380 \pm 8^{a}$ & $3261 \pm 55^{\mathrm{b}}$ & $6658 \pm 150^{\mathrm{c}}$ \\
\hline trans-3-Hexen-1-ol & $(\mu \mathrm{g} / \mathrm{L})$ & $1.7 \pm 0.1^{\mathrm{a}}$ & $40.4 \pm 0.3^{b}$ & $112.0 \pm 0.5^{\mathrm{c}}$ & $5.8 \pm 0.4^{\mathrm{a}}$ & $41.6 \pm 2.9^{b}$ & $93.8 \pm 3.6^{c}$ \\
\hline cis-3-Hexen-1-ol & $(\mu \mathrm{g} / \mathrm{L})$ & $\mathrm{ND}^{\mathrm{a}}$ & $\mathrm{ND}^{\mathrm{a}}$ & $2790 \pm 189^{b}$ & $\mathrm{ND}^{\mathrm{a}}$ & $\mathrm{ND}^{\mathrm{a}}$ & $1559 \pm 94^{b}$ \\
\hline Ethyl isobutyrate & $(\mu \mathrm{g} / \mathrm{L})$ & $12.9 \pm 0.3^{\mathrm{a}}$ & $5.4 \pm 0.9^{b}$ & $4.2 \pm 0.4^{\mathrm{b}}$ & $8.4 \pm 0.6^{\mathrm{a}}$ & $4.7 \pm 0.6^{\mathrm{b}}$ & $3.7 \pm 0.3^{b}$ \\
\hline Ethyl butanoate & $(\mu \mathrm{g} / \mathrm{L})$ & $554 \pm 1^{\mathrm{a}}$ & $734 \pm 46^{\mathrm{b}}$ & $669 \pm 34^{b}$ & $608 \pm 7^{a}$ & $527 \pm 11^{\mathrm{b}}$ & $535 \pm 28^{b}$ \\
\hline Ethyl hexanoate & $(\mu \mathrm{g} / \mathrm{L})$ & $1814 \pm 46^{\mathrm{a}}$ & $2648 \pm 92^{b}$ & $2768 \pm 74^{b}$ & $1916 \pm 57^{\mathrm{a}}$ & $1827 \pm 88^{a}$ & $1860 \pm 68^{a}$ \\
\hline Ethyl octanoate & (ug/L) & $761 \pm 43^{\mathrm{a}}$ & $1120 \pm 25^{b}$ & $1259 \pm 225^{c}$ & $1455 \pm 31^{\mathrm{a}}$ & $1646 \pm 62^{b}$ & $1700 \pm 40^{\mathrm{b}}$ \\
\hline Ethyl decanoate & $(\mu \mathrm{g} / \mathrm{L})$ & $261 \pm 35^{\mathrm{a}}$ & $494 \pm 19^{b}$ & $622 \pm 15^{c}$ & $524 \pm 44^{\mathrm{a}}$ & $770 \pm 38^{b}$ & $746 \pm 32^{b}$ \\
\hline Ethyl dodecanoate & $(\mu \mathrm{g} / \mathrm{L})$ & $47 \pm 12^{\mathrm{a}}$ & $56 \pm 7^{a, b}$ & $71 \pm 6^{b}$ & $44 \pm 5^{\mathrm{a}}$ & $54 \pm 7^{\mathrm{a}}$ & $51 \pm 10^{\mathrm{a}}$ \\
\hline Isobutyl acetate & $(\mu \mathrm{g} / \mathrm{L})$ & $13.3 \pm 0.9^{\mathrm{a}}$ & $17.2 \pm 0.4^{\mathrm{b}}$ & $15.2 \pm 0.9^{c}$ & $15.1 \pm 0.2^{\mathrm{a}}$ & $12.2 \pm 1.9^{a}$ & $14.2 \pm 0.6^{\mathrm{a}}$ \\
\hline Isoamyl acetate & $(\mu \mathrm{g} / \mathrm{L})$ & $6608 \pm 1539^{a}$ & $13,532 \pm 804^{b}$ & $10,092 \pm 688^{c}$ & $13,292 \pm 680^{a}$ & $8544 \pm 345^{b}$ & $7563 \pm 463^{b}$ \\
\hline Hexyl acetate & $(\mu \mathrm{g} / \mathrm{L})$ & $627 \pm 29^{a}$ & $2261 \pm 115^{b}$ & $4430 \pm 20^{c}$ & $487 \pm 20^{\mathrm{a}}$ & $1356 \pm 95^{b}$ & $1823 \pm 60^{c}$ \\
\hline cis-3-Hexenyl acetate & $(\mu \mathrm{g} / \mathrm{L})$ & $50 \pm 2^{a}$ & $184 \pm 5^{b}$ & $311 \pm 8^{c}$ & $35 \pm 3^{\mathrm{a}}$ & $84 \pm 4^{\mathrm{b}}$ & $147 \pm 7^{c}$ \\
\hline$\beta$-Phenylethyl acetate & $(\mu \mathrm{g} / \mathrm{L})$ & $412 \pm 75^{\mathrm{a}}$ & $1173 \pm 7^{b}$ & $802 \pm 48^{c}$ & $1122 \pm 55^{\mathrm{a}}$ & $820 \pm 19^{b}$ & $534 \pm 11^{c}$ \\
\hline Methyl octanoate & $(\mu \mathrm{g} / \mathrm{L})$ & $0.681 \pm 0.002^{\mathrm{a}}$ & $1.157 \pm 0.021^{\mathrm{b}}$ & $1.704 \pm 0.014^{\mathrm{c}}$ & $0.895 \pm 0.010^{\mathrm{a}}$ & $1.744 \pm 0.038^{b}$ & $2.440 \pm 0.041^{\mathrm{c}}$ \\
\hline Ethyl-(L)-lactate & $(\mu \mathrm{g} / \mathrm{L})$ & $6266 \pm 323^{a}$ & $5354 \pm 156^{\mathrm{b}}$ & $6080 \pm 155^{a}$ & $7617 \pm 59^{a}$ & $5718 \pm 817^{\mathrm{b}}$ & $5344 \pm 457^{\mathrm{b}}$ \\
\hline Diethyl succinate & $(\mu \mathrm{g} / \mathrm{L})$ & $219 \pm 22^{a}$ & $102 \pm 5^{b}$ & $87 \pm 3^{b}$ & $105 \pm 5^{\mathrm{a}}$ & $97 \pm 7^{\mathrm{a}, \mathrm{b}}$ & $91 \pm 3^{b}$ \\
\hline Isobutyric acid & $(\mathrm{mg} / \mathrm{L})$ & $0.66 \pm 0.02^{\mathrm{a}}$ & $0.95 \pm 0.06^{b}$ & $1.37 \pm 0.03^{c}$ & $1.08 \pm 0.03^{\mathrm{a}}$ & $1.75 \pm 0.08^{b}$ & $2.11 \pm 0.06^{\mathrm{c}}$ \\
\hline
\end{tabular}


Table 2. Cont.

\begin{tabular}{|c|c|c|c|c|c|c|c|}
\hline \multirow[b]{2}{*}{ Compound } & \multirow[b]{2}{*}{$\begin{array}{c}\text { Concentration } \\
\text { Units }\end{array}$} & \multicolumn{3}{|c|}{ Wairau Valley (A) } & \multicolumn{3}{|c|}{ Awatere Valley (B) } \\
\hline & & FR & LP & HP & FR & LP & HP \\
\hline Hexanoic acid & $(\mathrm{mg} / \mathrm{L})$ & $6.9 \pm 0.3^{a}$ & $7.7 \pm 0.3^{b}$ & $8.4 \pm 0.3^{b}$ & $6.8 \pm 0.3^{\mathrm{a}}$ & $6.4 \pm 0.2^{\mathrm{a}}$ & $6.7 \pm 0.3^{a}$ \\
\hline Octanoic acid & $(\mathrm{mg} / \mathrm{L})$ & $11.9 \pm 0.7^{\mathrm{a}}$ & $12.3 \pm 1.2^{\mathrm{a}}$ & $12.4 \pm 0.6^{\mathrm{a}}$ & $9.5 \pm 0.5^{a}$ & $8.2 \pm 0.3^{b}$ & $9.1 \pm 0.6^{\mathrm{a}, \mathrm{b}}$ \\
\hline Decanoic acid & $(\mathrm{mg} / \mathrm{L})$ & $2.7 \pm 0.2^{\mathrm{a}}$ & $0.8 \pm 0.6^{\mathrm{b}}$ & $2.3 \pm 0.3^{\mathrm{a}}$ & $1.0 \pm 0.2^{\mathrm{a}}$ & $0.3 \pm 0.2^{b}$ & $0.5 \pm 0.2^{b}$ \\
\hline Isobutanol & $(\mu \mathrm{g} / \mathrm{L})$ & $16,972 \pm 1474^{\mathrm{a}}$ & $22,601 \pm 1214^{b}$ & $20,169 \pm 1751^{a, b}$ & $25,484 \pm 848^{a}$ & $23,043 \pm 396^{a}$ & $23,783 \pm 1545^{a}$ \\
\hline Butan-1-ol & $(\mu \mathrm{g} / \mathrm{L})$ & $1155 \pm 92^{a}$ & $990 \pm 28^{a}$ & $806 \pm 79^{b}$ & $1340 \pm 68^{a}$ & $803 \pm 24^{b}$ & $789 \pm 40^{b}$ \\
\hline Isoamyl alcohol & $(\mu \mathrm{g} / \mathrm{L})$ & $154,756 \pm 9212^{\mathrm{a}}$ & $181,938 \pm 8111^{b}$ & $152,970 \pm 7739^{a}$ & $194,812 \pm 2275^{a}$ & $160,303 \pm 4842^{b}$ & $160,940 \pm 5409^{b}$ \\
\hline Methionol & $(\mu \mathrm{g} / \mathrm{L})$ & $1831 \pm 16^{\mathrm{a}}$ & $1033 \pm 44^{b}$ & $1356 \pm 276^{\mathrm{b}}$ & $1471 \pm 363^{a}$ & $995 \pm 114^{a}$ & $928 \pm 49^{\mathrm{a}}$ \\
\hline Benzyl alcohol & $(\mu \mathrm{g} / \mathrm{L})$ & $52 \pm 4^{\mathrm{a}}$ & $125 \pm 2^{a}$ & $540 \pm 51^{\mathrm{b}}$ & $80 \pm 2^{a}$ & $195 \pm 15^{\mathrm{b}}$ & $507 \pm 2^{c}$ \\
\hline Phenylethyl alcohol & $(\mu \mathrm{g} / \mathrm{L})$ & $26,421 \pm 1053^{a}$ & $40,779 \pm 1077^{b}$ & $34,805 \pm 1880^{c}$ & $37,583 \pm 840^{a}$ & $37,064 \pm 570^{a}$ & $33,271 \pm 306^{b}$ \\
\hline Benzaldehyde & $(\mu \mathrm{g} / \mathrm{L})$ & $0.41 \pm 0.02^{\mathrm{a}}$ & $12.50 \pm 0.23^{b}$ & $20.33 \pm 2.05^{c}$ & $0.64 \pm 0.06^{\mathrm{a}}$ & $19.03 \pm 1.63^{b}$ & $47.17 \pm 1.95^{\mathrm{c}}$ \\
\hline Ethyl cinnamate & $(\mu \mathrm{g} / \mathrm{L})$ & $0.169 \pm 0.001^{\mathrm{a}}$ & $0.397 \pm 0.011^{\mathrm{b}}$ & $0.692 \pm 0.040^{\mathrm{c}}$ & $0.290 \pm 0.016^{\mathrm{a}}$ & $0.445 \pm 0.007^{\mathrm{b}}$ & $0.577 \pm 0.016^{\mathrm{c}}$ \\
\hline $\begin{array}{c}\text { Ethyl } \\
\text { dihydrocinnamate }\end{array}$ & $(\mu \mathrm{g} / \mathrm{L})$ & $0.418 \pm 0.018^{\mathrm{a}}$ & $0.657 \pm 0.003^{b}$ & $0.668 \pm 0.014^{b}$ & $0.704 \pm 0.005^{\mathrm{a}}$ & $0.858 \pm 0.021^{\mathrm{b}}$ & $0.884 \pm 0.024^{b}$ \\
\hline 4-Vinylphenol & $(\mu \mathrm{g} / \mathrm{L})$ & $388 \pm 1^{\mathrm{a}}$ & $296 \pm 37^{b}$ & $102 \pm 6^{c}$ & $1,186 \pm 59^{a}$ & $206 \pm 23^{b}$ & $96 \pm 8^{c}$ \\
\hline 4-Vinylguaiacol & $(\mu \mathrm{g} / \mathrm{L})$ & $143 \pm 3^{a}$ & $141 \pm 15^{\mathrm{a}}$ & $181 \pm 2^{b}$ & $270 \pm 3^{a}$ & $179 \pm 14^{b}$ & $132 \pm 1^{\mathrm{c}}$ \\
\hline
\end{tabular}

FR $=$ Free Run, $\mathrm{LP}=$ Light Press and HP $=$ Heavy Press. The letters $(\mathrm{a}, \mathrm{b}, \mathrm{c})$ denote homogeneous subsets as determined by Tukey's HSD. ND = not detected. 


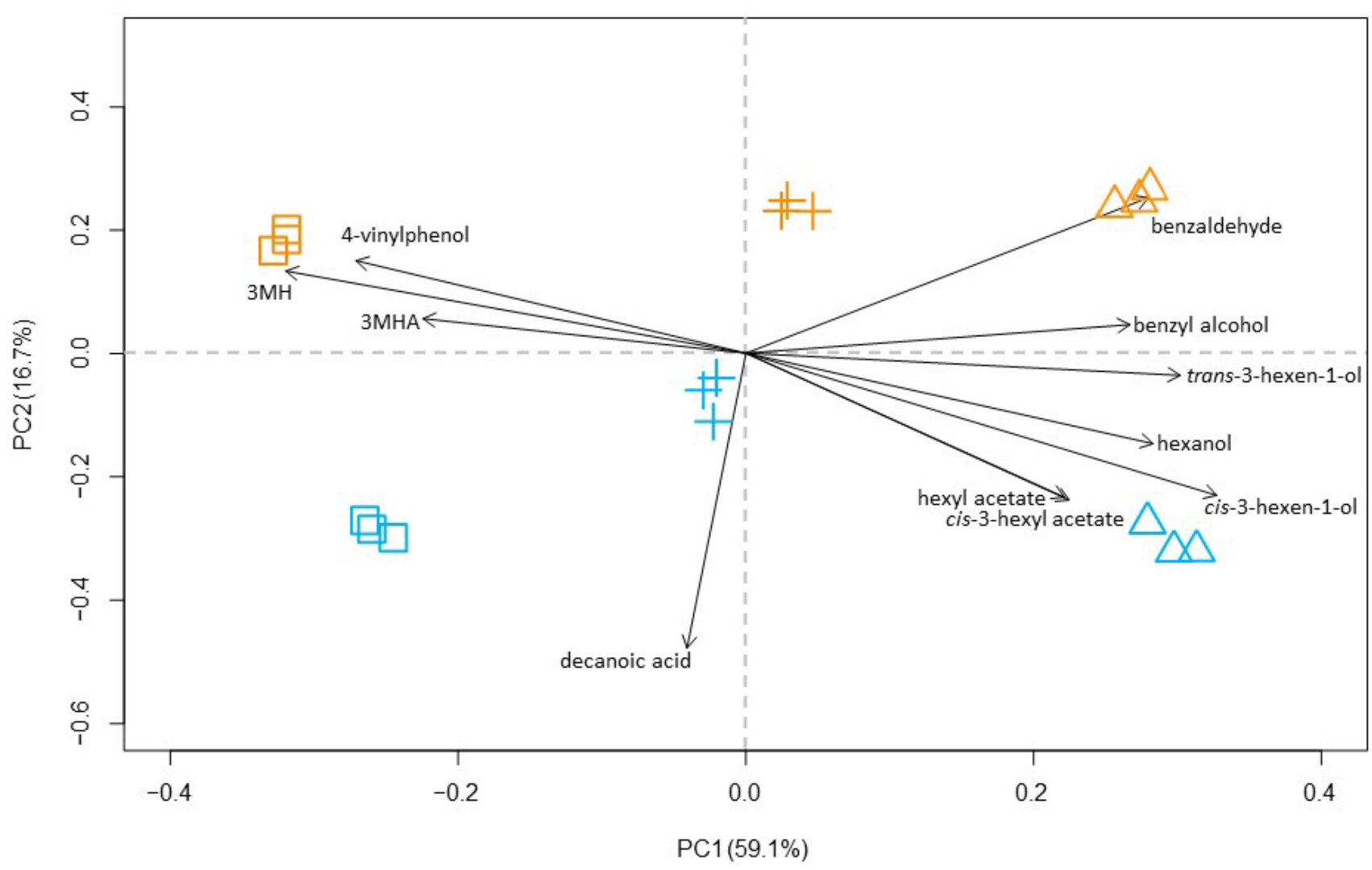

Figure 1. PCA biplot constructed using the aroma chemistry data of experimental wines identified by Wairau (set A) in blue and Awatere (set B) in orange, with fractions denoted as Free Run = Square, Light Press = Cross and Heavy Press = Triangle. Directional forces of those compounds that satisfy Mardia's criterion are displayed with arrows.

A stark separation of the FR and HP wines to the left and right, respectively, of PC1 is observed. Additionally, to the left of PC1 are the loadings for $3 \mathrm{MH}$ and 3MHA, and, as expected, these two polyfunctional mercaptans were found to be at the highest concentration in the FR wines for each set. The highest average concentration for each (2368 and $705 \mathrm{ng} / \mathrm{L}$ for 3MH and 3MHA, respectively) was found in the FR wines of set $\mathrm{B}$, which is also demonstrated in the PCA by the proximity of these loadings to the set B FR wines. Previous studies have shown that wines made from more oxidised juices, including pressed juices, can produce lower amounts of 3MH and 3MHA [2,4], which agrees with the observations of this study. Likewise, maintaining adequate antioxidant protection, as seen in the free $\mathrm{SO}_{2}$ levels, can greatly influence the levels of these two aroma compounds [7-10]. From the post-pressing analysis of the experimental juices, the more extensive pressing program to collect the LP and HP fractions led to a severe depletion in available antioxidants (including free $\mathrm{SO}_{2}$ ) at that point, and was a likely contributor to the lower concentrations of $3 \mathrm{MH}$ and $3 \mathrm{MHA}$ recorded for these wines. The higher $\mathrm{pH}$ of the pressed juices and wines also needs to be considered as a contributing factor in future research.

Among the compounds that can contribute to green and capsicum aromas, quite similar concentrations of the methoxypyrazine IBMP were obtained across the wines at 3.7 to $6.2 \mathrm{ng} / \mathrm{L}$ (Table 2). The most abundant $\mathrm{C}_{6}$ compound was hexanol, with values ranging between 380 and 10,195 $\mu \mathrm{g} / \mathrm{L}$, and with significant increases moving from the FR to the HP wines for both sets. This is consistent with an earlier study with Emir grapes [13], and with the range of hexanol levels previously reported in Sauvignon blanc with averages around $2500 \mu \mathrm{g} / \mathrm{L}[3,30]$ or even above $6000 \mu \mathrm{g} / \mathrm{L}$ in press fraction wines [22]. Both cis-3-hexen-1-ol and trans-3-hexen-1-ol exhibited the same upwards trend between press fractions, while 
no cis-3-hexen-1-ol was detected in both sets of FR and LP wines. Increasing amounts of these $\mathrm{C}_{6}$ compounds could be expected as more of the unsaturated linoleic and linolenic fatty acids are extracted when grape cells are ruptured in the presence of oxygen [31]. This strong association of these three $\mathrm{C}_{6}$ compounds is reflected in the PCA of Figure 1, with their respective loadings pulling to the right of PC1.

The esters that showed a consistent and significant increase in both wine sets from fractions FR through to HP were methyl octanoate, cis-3-hexenyl acetate and hexyl acetate (Table 2). The two latter esters were identified by Mardia's criterion as important drivers for the separation of the experimental wines along PC1 (Figure 1). These esters have been confirmed to be highly positively correlated to the presence of hexanol in wines made from heavy press regimes [32], a finding which is reinforced by their positioning in the same quadrant as hexanol on the biplot (Figure 1). The esters ethyl isobutyrate, ethyl-(L)-lactate and diethyl succinate all showed their highest concentrations in the FR fractions with both sets of wines.

Other significant relationships included the elevated presence of benzyl alcohol and benzaldehyde from wines consisting of heavier pressed juices (Table 2), highlighted on the PCA biplot with both loadings residing to the right of PC1. Benzyl alcohol and benzaldehyde have been recorded at a higher concentration in wines made from Sauvignon blanc pressed juices [22]. It is well known that the presence of oxygen during fermentation can result in the formation of higher alcohols and, in turn, their associated aldehydes [33], which can also be released from bound forms in the grapes and with further conversions expected during fermentation. Hence, their elevated levels in HP wines seems reasonable, given the extra time and exposure to the atmosphere as the pressing cycles move from FR to HP. The opposite was found for butan-1-ol, which showed a decreasing trend from FR to $\mathrm{HP}$ wines.

Of all the aroma compounds considered during this trial, only one was seen to drive the partitioning of the experimental wines along PC2 (Figure 1). This was decanoic acid, which was located to the bottom of the biplot from the origin. This fatty acid has previously been demonstrated to vary between musts [34], with different proportions of branched chain amino acids able to modulate the amount present [35]. When viewing the average concentrations of this compound in Table 2, there is no clear increase nor decrease in this compound when moving from the FR to the HP wines, although the lowest levels were seen in the LP wines in both sets. A more general overview of the biplot reveals that PC2 is responsible for the separation of set $A$ from set $B$, and not so much the distinction between the pressing fractions. The FR wines of set A contained the highest levels of decanoic acid $(2.7 \mathrm{mg} / \mathrm{L})$, followed by the HP wines of set A $(2.3 \mathrm{mg} / \mathrm{L})$, while all of the set B wines had less than $1.0 \mathrm{mg} / \mathrm{L}$ of decanoic acid.

In the upper left-hand quadrant of the biplot, 4-vinylphenol is also visible. This compound was seen to significantly decrease when moving from FR to HP wines for both sets. Its association and direction towards the same side of PC1 as the FR wines is perhaps less expected. Although machine harvesting and hard pressing procedures can cause an increase in this compound due to higher concentrations of phenolic acids coming from the grape solids, it has also been noted that juices with insufficient antioxidant protection can also be responsible for decreases in certain phenolics such as $p$-coumaric acid, which is important for the synthesis of 4 -vinylphenol [36,37]. The concentration of trans-coutaric, a source of $p$-coumaric acid in the wine, was found to decrease in the juices as the pressing program advanced in a previous report [22], although these compounds were not detected in juice analyses in the current trial. Due to the sensory characteristics of this compound (medicinal), the reasons for its higher levels in the FR wines deserve more attention in future work.

In addition to the aroma compounds that feature in the PCA of Figure 2, some further differences in concentrations related to press fractions can be noted. Cis/trans-rose oxide and $\beta$-citronellol showed increasing concentrations in moving from FR to HP wines (Table 2). An increase was also seen with linalool for set B with greater pressing, while no significant 
difference was seen within the linalool concentrations for set A. $\beta$-Damascenone was seen to significantly decrease in the LP and HP fractions for both wine sets. $\beta$-Ionone, a norisoprenoid described as having violet notes, was also found at the highest values in the FR wines.
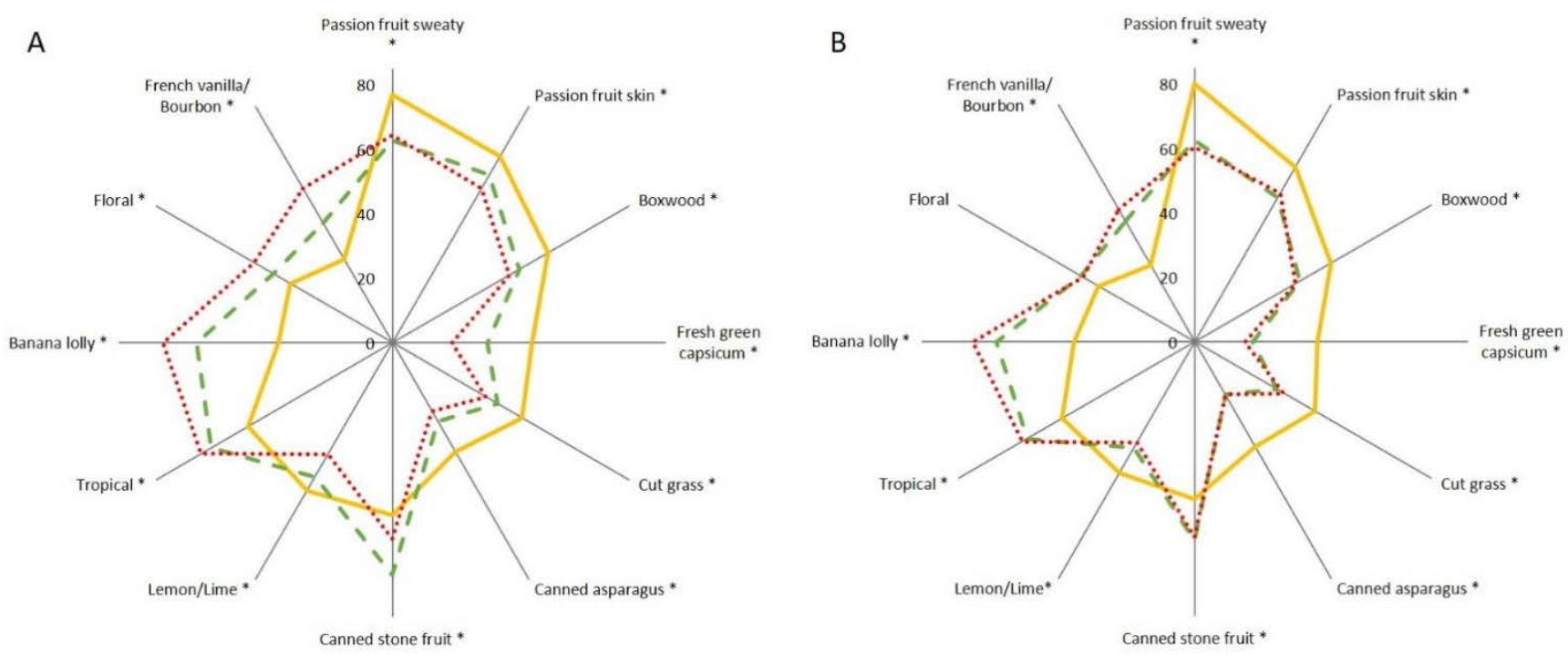

Figure 2. Sensory evaluation results of the Wairau (A) and Awatere (B) wine sets are on the left and right, respectively. Panel averages for the fermentation replicates are shown for each of the 12 aroma attributes evaluated, with significant attributes denoted by *. Free Run = solid line, Light Press = dashed line and Heavy Press = dotted line.

\subsection{Sensory Evaluation}

The spider plots in Figure 2 show which attributes the panel found to be significant in distinguishing the wines for each set $(p<0.05)$. For wine set $\mathrm{A}$, all the attributes tested were significant, whereas, in set $\mathrm{B}$, all attributes except Floral were significant. The panelists rated Passionfruit/sweaty, Passionfruit skin, Boxwood, Fresh green capsicum, Cut grass, Canned asparagus and Lemon/lime higher in the FR wines for each set. Passionfruit and Boxwood sensory attributes are associated with 3MH, 3MHA and 4MMP [1], and these compounds were used as the reference standards for Passionfruit/sweaty, Passionfruit skin and Boxwood, respectively. Although 4MMP was not quantified during this study, $3 \mathrm{MH}$ and 3MHA were present at the highest concentrations in the FR wines of each set, which is consistent with the sensory data. FR wines were also more predominantly characterised by Cut grass notes, while LP and HP wines were notably higher in French vanilla/bourbon $(p<0.01)$, the label given by the panelists to the reference standard of hexanol in a base wine (Supplementary Table S2). This finding relates well to the observations from the aroma chemistry analysis, where higher levels of hexanol were found when moving from the FR to the HP wines in each set.

Other sensory attributes giving higher average values for the LP and HP wines were Canned stone fruit, Tropical, Banana lolly, and Floral. Isoamyl acetate and hexyl acetate were used in combination to help create the reference standard for Banana lolly as they both contribute fruity aromas $[11,38]$. For both sets A and B, hexyl acetate was seen to increase markedly across the press fractions FR to HP, which would support the sensory trends, while isoamyl acetate was more variable in its concentrations. Other fruity esters such as ethyl octanoate and ethyl decanoate may have contributed to this Banana lolly attribute, as well as the Tropical and Canned stone fruit aromas exhibited by the heavier pressed wines, as they were all seen to increase in the LP and HP wines. The chemical compound ethyl dihydrocinnamate has a fruity, pineapple and even almond aroma $[39,40]$, and interestingly, was seen to increase for the FR wines to slightly higher values within the LP and HP fraction wines in each set. The sensory attribute Banana lolly has been 
used as a descriptor for Sauvignon blanc wines in further studies, with the finding that wines made from juices without any antioxidants can result in higher ratings for this descriptor [10]. An accompanying chemical analysis was not able to pinpoint the origin of this descriptor and, instead, it was suggested that its increase could be due to a decrease in polyfunctional mercaptans, which were thought to have a masking effect when present in high enough concentrations. This unmasking effect could also apply to the HP wines in the present study.

The Floral attribute also had a higher average in the LP and HP wines of both sets; however, it was the only sensory attribute not found to be statistically significantly different in both wine sets. Floral aroma compounds that increased significantly from FR to HP include cis/trans-rose oxide, $\alpha$-terpineol, $\beta$-citronellol and nerol for sets A and B, as well as linalool for set B. These compounds are particularly important to floral wines such as Muscat varieties, although one study has suggested that Sauvignon blanc lies between both floral and non-floral grape varieties, being monoterpene dependent and monoterpene deficient [15]. The effect of omitting certain terpenes from Sauvignon blanc was shown to increase the Cats Pee and Sweet-Sweaty Passionfruit aromas while lessening Apple lolly, Stonefruit, and Tropical, even when these terpenes were well below their Odor Activity Values in the Sauvignon blanc wine [41]. The diminished amount of 3MHA may also be influencing this change in floral aroma, as it has been found to have a negative effect on the presence of sweet, muscat and floral aromas in wine [40].

\section{Conclusions}

Several aroma compounds were identified to be important when distinguishing wines made from different juice fractions. Factors involved in distinguishing the juices included lower levels of free $\mathrm{SO}_{2}$ and phenolic compounds in the pressed juices, possibly due to oxidation processes, but with a higher $\mathrm{pH}$ and lower percentage of solids, both of which may also have effects on fermentation performance and ultimate wine composition. The significance of $3 \mathrm{MH}$ and $3 \mathrm{MHA}$ was established for FR wines, as well as certain $\mathrm{C}_{6}$ alcohols and their related compounds for outlining the profile of a HP wine. Sensory evaluation demonstrated the ability of the French vanilla/bourbon descriptor to discriminate the wines, which agreed with the significant increase in hexanol observed throughout the press fractions, and that of the polyfunctional mercaptans for Passionfruit-based descriptors. The two wine sets were very similar in how the sensory profiles of the wines reflected the press fractions they had been made from. Overall, the collation of chemical and sensory results from this study demonstrates the range of profiles that can be obtained using different pressing regimes, providing useful information for winemakers.

Supplementary Materials: The following are available online at https://www.mdpi.com/article/ 10.3390/beverages7020029/s1, Table S1: Compounds identified during the GC-MS analysis of the experimental wines along with their respective retention times, ions used for qualification and quantification as well as the $\mathrm{R}^{2}$ of their calibration equation; Table S2: Sensory attributes and their reference standards used in the sensory evaluation; Table S3: Averages \pm standard deviations of certain polyphenols found in the experimental juices; Table S4: Averages and standard deviations $( \pm)$ of the fermentation triplicates for some basic wine parameters after fermentation; Table S5: Simplified PERMANOVA.

Author Contributions: Conceptualization, K.P.-V., F.B. and P.A.K.; methodology, K.P.-V., F.B., M.H.-J. and R.C.D.; data interpretation, K.P.-V., F.B., B.F. and P.A.K.; writing—original draft preparation, K.P.V.; writing—review and editing, K.P.-V., M.H.-J., F.B., B.F., R.C.D. and P.A.K.; supervision, M.H.-J., F.B. and P.A.K. All authors have read and agreed to the published version of the manuscript.

Funding: This research was funded by the New Zealand Ministry of Business, Innovation and Employment through TechNZ Capability Education Funding.

Institutional Review Board Statement: The study was conducted according to the guidelines and approval of The University of Auckland Human Participants Ethics Committee (UAHPEC), Ethics approval no. 8306. 
Informed Consent Statement: Informed consent was obtained from all subjects involved in the study.

Data Availability Statement: All of the data is contained within the article.

Acknowledgments: The authors would like to thank Delegat Limited, New Zealand, for the donation of juice and continued support of this project, along with Pernod Ricard, New Zealand, for the use of the FOSS WineScanTM FT120 and FIAstarTM 5000 Analyzer. Olga Makhotkina is thanked for her role in training the sensory panel.

Conflicts of Interest: The authors declare no conflict of interest.

\section{References}

1. Tominaga, T.; Furrer, A.; Henry, R.; Dubourdieu, D. Identification of new volatile thiols in the aroma of Vitis. vinifera L. var. Sauvignon blanc wines. Flavour Fragr. J. 1998, 13, 159-162. [CrossRef]

2. Allen, T.; Herbst-Johnstone, M.; Girault, M.; Butler, P.; Logan, G.; Jouanneau, S.; Nicolau, L.; Kilmartin, P. Influence of grapeharvesting steps on varietal thiol aromas in Sauvignon blanc wines. J. Agric. Food Chem. 2011, 59, 10641-10650. [CrossRef] [PubMed]

3. Benkwitz, F.; Tominaga, T.; Kilmartin, P.A.; Lund, C.; Wohlers, M.; Nicolau, L. Identifying the chemical composition related to the distinct aroma characteristics of New Zealand Sauvignon blanc wines. Am. J. Enol. Vitic. 2012, 63, 62-72. [CrossRef]

4. Patel, P.; Herbst-Johnstone, M.; Lee, S.; Gardner, R.; Weaver, R.; Nicolau, L.; Kilmartin, P. Influence of juice pressing conditions on polyphenols, antioxidants, and varietal aroma of Sauvignon blanc microferments. J. Agric. Food Chem. 2010, 58, 7280-7288. [CrossRef]

5. Nikolantonaki, M.; Thibon, C.; Shinoda, K.; Teissedre, P.L.; Darriet, P. Levels and influence of flavan-3-ol must content on varietal aroma of young Sauvignon blanc wines: Effects of pressing conditions, grape origin and vintage. In Proceedings of the International Symposium of Oenology (OENO), Bordeaux, France, 15-17 June 2011.

6. Roland, A.; Schneider, R.; Charrier, F.; Cavelier, F.; Rossignol, M.; Razungles, A. Distribution of varietal thiol precursors in the skin and the pulp of Melon B. and Sauvignon blanc grapes. Food Chem. 2011, 125, 139-144. [CrossRef]

7. Makhotkina, O.; Herbst-Johnstone, M.; Logan, G.; du Toit, W.; Kilmartin, P.A. Influence of sulfur dioxide additions at harvest on polyphenols, C6-compounds, and varietal thiols in Sauvignon blanc. Am. J. Enol. Vitic. 2013, 64, 203-213. [CrossRef]

8. Makhotkina, O.; Araujo, L.D.; Olejar, K.; Herbst-Johnstone, M.; Fedrizzi, B.; Kilmartin, P.A. Aroma impact of ascorbic acid and glutathione additions to sauvignon Blanc at harvest to supplement sulfur dioxide. Am. J. Enol. Vitic. 2014, 65, 388-393. [CrossRef]

9. Coetzee, C.; Lisjak, K.; Nicolau, L.; Kilmartin, P.; du Toit, W.J. Oxygen and sulfur dioxide additions to Sauvignon blanc must: Effect on must and wine composition. Flavour Fragr. J. 2013, 28, 155-167. [CrossRef]

10. Lyu, X.; Dias Araujo, L.; Quek, S.-Y.; Kilmartin, P.A. Effects of antioxidant and elemental sulfur additions at crushing on aroma profiles of Pinot Gris, Chardonnay and Sauvignon Blanc wines. Food Chem. 2021, 346, 128914. [CrossRef]

11. Escudero, A.; Campo, E.; Ugliano, M. Analytical characterisation of the aroma of five premium red wines. Insights into the role of odor families and the concept of fruitiness of wines. J. Agric. Food Chem. 2007, 55, 4501-4510. [CrossRef]

12. Moyano, L.; Zea, L.; Moreno, J.; Medina, M. Analytical study of aromatic series in sherry wines subjected to biological aging. J. Agric. Food Chem. 2002, 50, 7356-7361. [CrossRef] [PubMed]

13. Selli, S.; Bagatar, B.; Sen, K.; Kelebek, H. Evaluation of differences in the aroma composition of free-run and pressed neutral grape juices obtained from emir (Vitis vinifera L.). Chem. Biodivers. 2011, 8, 1776-1782. [CrossRef] [PubMed]

14. Augustyn, O.; Rapp, A.; Wyk, C. Some volatile aroma components of Vitis vinifera L. cv. Sauvignon blanc. S. Afr. J. Enol. Vitic. 1982, 3, 53-60. [CrossRef]

15. Sefton, M.; Francis, I.; Williams, P. Free and bound volatile secondary metabolites of Vitis vinifera grape cv. Sauvignon blanc. J. Food Sci. 1994, 59, 142-147. [CrossRef]

16. Marais, J.; van Wyk, C. Effect of grape maturity and juice temperature on terpene concentrations and wine quality of Vitis vinifera L. cv. Weisser, Riesling and Bukettraube. S. Afr. J. Enol. Vitic. 1986, 7, 26-35.

17. Louw, L.; Tredoux, A.; Van Rensberg, P.; Kidd, M.; Naes, T.; Nieuwoudt, H. Fermentation-derived aroma compounds in varietal young wines from South Africa. S. Afr. J. Enol. Vitic. 2010, 31, 213-225. [CrossRef]

18. Boulton, B.; Singleton, V.; Bisson, L.; Kunkee, R. Principals and Practices of Winemaking; Chapman \& Hall: New York, NY, USA, 1999.

19. Hebditch, K.R.; Nicolau, L.; Brimble, M.A. Synthesis of isotopically labelled thiol volatiles and cysteine conjugates for quantification of Sauvignon Blanc wine. J. Label. Compd. Radiopharm. 2007, 50, 237-243. [CrossRef]

20. Maggu, M.; Winz, R.; Kilmartin, P.; Trought, M.; Nicolau, L. Effect of skin contact and pressure on the composition of Sauvignon blanc must. J. Agric. Food Chem. 2007, 55, 10281-10288. [CrossRef]

21. Parr, W.V.; Green, J.A.; White, K.G.; Sherlock, R.R. The distinctive flavour of New Zealand Sauvignon blanc: Sensory characterisation by wine professionals. Food Qual. Prefer. 2007, 18, 849-861. [CrossRef]

22. Parish, K.J.; Herbst-Johnstone, M.; Bouda, F.; Klaere, S.; Fedrizzi, B. Pre-fermentation fining effects on the aroma chemistry of Marlborough Sauvignon blanc press fractions. Food Chem. 2016, 208, 326-335. [CrossRef] 
23. Pinu, F.R.; Edwards, P.J.B.; Jouanneau, S.; Kilmartin, P.A.; Gardner, R.C.; Villas-Boas, S.G. Sauvignon blanc metabolomics: Grape juice metabolites affecting the development of varietal thiols and other aroma compounds in wines. Metabolomics 2014, 10, 556-573. [CrossRef]

24. Lund, C.M.; Thompson, M.K.; Benkwitz, F.; Wohler, M.W.; Triggs, C.M.; Gardner, R.; Heymann, H.; Nicolau, L. New Zealand Sauvignon blanc distinct flavor characteristics: Sensory, chemical, and consumer Aspects. Am. J. Enol. Vitic. 2009, 60, 1-12.

25. R Core Team. R: A Language and Environment for Statistical Computing; R Foundation for Statistical Computing: Vienna, Austria, 2014.

26. Oksanen, J.; Guillaume Blanchet, F.; Kindt, R.; Legendre, P.; Minchin, P.R.; O’Hara, R.B.; Simpson, G.L.; Solymos, P.; Henry, M.; Stevens, H.; et al. Vegan: Community Ecology Package; R package version 2.0-10. 2013. Available online: https:// www.researchgate.net/publication/258996451_Vegan_Community_Ecology_Package_R_Package_Version_20-10 (accessed on 10 January 2021).

27. Jolliffe, I. Principal Component Analysis; Springer: New York, NY, USA, 1986.

28. Mardia, K.V.; Kent, J.T.; Bibby, J. Multivariate Analysis; Academic Press: London, UK, 1979.

29. Zoecklein, B.W.; Fugelsang, K.C.; Gump, B.H.; Nury, F.S. Wine Analysis and Production; Aspen Publishers Inc.: Gaithersburg, MD, USA, 1999.

30. Jouanneau, S.; Weaver, R.; Nicolau, L.; Herbst-Johnstone, M.; Benkwitz, F.; Kilmartin, P. Subregional survey of aroma compounds in Marlborough Sauvignon blanc wines. Aust. J. Grape Wine Res. 2012, 18, 329-343. [CrossRef]

31. Marais, J. Sauvignon blanc cultivar aroma-A review. S. Afr. J. Enol. Vitic. 1994, 15, 41-45. [CrossRef]

32. Parish, K.J.; Herbst-Johnstone, M.; Bouda, F.; Klaere, S.; Fedrizzi, B. Sauvignon Blanc aroma and sensory profile modulation from high fining rates. Aust. J. Grape Wine Res. 2017, 23, 359-367. [CrossRef]

33. Tarko, T.; Duda-Chodak, A.; Sroka, P.; Siuta, M. The Impact of Oxygen at Various Stages of Vinification on the Chemical Composition and the Antioxidant and Sensory Properties of White and Red Wines. Int. J. Food Sci. 2020, 2020, 7902974. [CrossRef]

34. Edwards, C.G.; Beelman, R.B.; Bartley, C.E.; McConnell, A.L. Production of Decanoic Acid and Other Volatile Compounds and the Growth of Yeast and Malolactic Bacteria During Vinification. Am. J. Enol. Vitic. 1990, 41, 48-56.

35. Liu, P.T.; Yu, K.J.; Li, Y.T.; Duan, C.Q.; Yan, G.L. The content of linoleic acid in grape must influences the aromatic effect of branched-chain amino acids addition on red wine. Food Res. Int. 2018, 114, 214-222. [CrossRef]

36. Ribéreau-Gayon, P.; Glories, Y.; Maujean, A.; Dubourdieu, D. (Eds.) Handbook of Enology; John Wiley \& Sons, LTD: West Sussex, UK, 2001; Volume 2.

37. Chatonnet, P.; Dubourdie, D.; Boidron, J.-n.; Pons, M. The origin of ethylphenols in wines. J. Sci. Food Agric. 1992, 60, 165-178. [CrossRef]

38. Pineau, B.; Barbe, J.; van Leeuwen, C.; Dubourdieu, D. Which impact for beta-damascenone on red wine aromas? J. Agric. Food Chem. 2007, 55, 4103-4108. [CrossRef]

39. Antalick, G.; Perello, M.-C.; de Revel, G. Development, validation and application of a specific method for the quantitative determination of wine esters by headspace-solid-phase microextraction-gas chromatography-mass spectrometry. Food Chem. 2010, 121, 1236-1245. [CrossRef]

40. Campo, E.; Ferreira, V. Prediction of the wine sensory properties related to grape variety form dynaimc-headspace gas chromatography-olfactometry data. J. Agric. Food Chem. 2005, 53, 5682-5690. [CrossRef] [PubMed]

41. Benkwitz, F.; Nicolau, L.; Lund, C.; Beresford, M.; Wohlers, M.; Kilmartin, P.A. Evaluation of key odorants in sauvignon blanc wines using three different methodologies. J. Agric. Food Chem. 2012, 60, 6293-6302. [CrossRef] [PubMed] 